\title{
HUBUNGAN TINGKAT STRES, KEMATANGAN EMOSI, DENGAN JENIS PERILAKU KOPING ORANG TUA ABK DI KOTA MALANG
}

\author{
Aryudho Widyatno \\ Fakultas Pendidikan Psikologi, Universitas Negeri Malang \\ aryudho.widyatno.fppsi@um.ac.id \\ Adi Atmoko \\ Fakultas Ilmu Pendidikan, Universitas Negeri Malang \\ adi.atmoko.fip@um.ac.id \\ Diantini Ida Viatrie \\ Fakultas Pendidikan Psikologi, Universitas Negeri Malang \\ diantini.ida.fppsi@um.ac.id
}

\begin{abstract}
Abstrak
Penelitian ini bertujuan untuk mendapatkan gambaran tentang tingkat stres, kematangan emosi, serta penerapan perilaku koping yang digunakan oleh orang tua yang memiliki anak dengan kebutuhan khusus di kota malang. Penelitian ini juga akan mengungkap hubungan antara tingkat stres, kematangan emosi, serta jenis perilaku koping yang berfokus pada masalah atau berfokus pada emosi. Instrumen yang digunakan dalam penelitian ini adalah skala tingkat stress, skala kematangan emosi, dan skala jenis perilaku koping. Hasil penelitian ini menunjukkan bahwa orang tua anak yang memiliki anak berkebutuhan khusus di kota malang memiliki tingkat stres serta kematangan emosi yang tergolong sangat bervariatif, orang tua tersebut cenderung menerapkan perilaku koping berganti-ganti tergantung pemaknaan suatu masalah. Dari analisis regresi yang ditunjukkan terlihat bahwa terdapat hubungan antara tingkat stres, kematangan emosi dengan jenis perilaku koping orang tua yang memiliki anak berkebutuhan khusus di kota malang. tingkat stress memiliki hubungan positif terhadap jenis perilaku koping orang tua ABK, sedangkan kematangan emosi memiliki hubungan negatif terhadap jenis perilaku koping orang tua ABK di kota malang
\end{abstract}

Kata Kunci: tingkat stres, kematangan emosi, perilaku koping

\begin{abstract}
This study aims to get an overview of stress levels, emotional maturity, and the application of coping behaviors used by parents who have children with special needs in the city of Malang. This study will also reveal the relationship between stress levels, emotional maturity, and types of coping behaviors that focus on the problem or focus on emotions. The instruments used in this study were the scale of stress level, emotional maturity scale, and scale of coping behavior. The results of this study indicate that parents of children who have children with special needs in the city of Malang have stress levels and emotional maturity which are classified as very varied, these parents tend to apply alternating coping behavior depending on the meaning of a problem. From the regression analysis shown that there is a relationship between stress levels, emotional maturity and the type of coping behavior of parents who have children with special needs in the city of Malang. stress level has a positive relationship to the type of coping behavior of ABK parents, while emotional maturity has a negative relationship to the type of coping behavior of $\mathrm{ABK}$ parents in Malang city
\end{abstract}

Keywords: stress level, emotional maturity, coping behavior

Pertumbuhan anak berkebutuhan khusus dalam beberapa tahun terakhir ini menunjukkan kecenderungan peningkatan yang sangat pesat. Data dari Dinas Pendidikan Luar Biasa Kementrian Pendidikan Nasional menyebutkan bahwa di Indonesia terdapat 324.000 anak penderita ABK. (Joglo Semar: 2010). Hal ini sejalan dengan apa yang disampaikan oleh Dr. Seto Mulyadi yang menyatakan bahwa prevalensi pertumbuhan anak berkebutuhan khusus di Indonesia, saat ini sekitar 1:250 dari setiap kelahiran. (YCHI Center: 2011).

Adanya anak berkebutuhan khusus dalam sebuah keluarga, bukanlah hal yang mudah untuk dihadapi oleh hampir setiap orang tua. Keluarga dengan anak berkebutuhan khusus memiliki pengalaman dan bentuk interaksi yang berbeda dibandingkan keluarga lain pada umumnya. Kehadiran anak berkebutuhan khusus memberikan 
beban yang berat bagi orang tua, karena mereka harus memberikan penanganan yang intensif dalam berbagai aspek (bahasa, tingkah laku, fisik, dan sensorik) sejak anak masih kecil. Penanganan secara terpadu ini sudah tentu membutuhkan biaya yang tidak sedikit. Selain itu setiap harinya orang tua juga harus berhadapan dengan masalah tingkah laku anak berkebutuhan khusus seperti agresifitas, hiperaktifitas, tidak dapat berkonsentrasi, tantrum dan menyakiti diri sendiri. Kesulitan anak berkebutuhan khusus dalam memahami bahasa dan berkomunikasi amat menyulitkan orang tua untuk menerapkan aturan dan memberikan penjelasan pada anak tentang kejadian sehari-hari.

Mungkin tidak bisa dipungkiri, orang tua yang mempunyai anak berkebutuhan khusus untuk pertama kalinya mereka tidak mudah menerima kenyataan bahwa anaknya menderita kelainan. Banyak dokter dan tenaga professional dalam kesehatan mental mengamati bahwa saat orang tua mengetahui anak mereka memiliki kebutuhan khusus reaksi yang muncul pada saat mereka mengetahui bahwa anaknya menderita kelainan, seperti munculnya perasaan terpukul dan bingung. Dari perasaan-perasaan inilah kemudian timbul reaksi yang beragam antara lain rasa bersalah, rasa kecewa, rasa malu, dan rasa menerima apa adanya (Moerdiani, A.S. 1987).

Penelitian yang berkaitan dengan parental stress ini dilakukan oleh Kazdin dan Whitley (2003), menyatakan bahwa adanya stres yang dialami orang tua karena perilaku anak yang tidak dapat diterima oleh orang tua yang mungkin dapat mengurangi hubungan orang tua - anak dan mengurangi kualitas pengasuhan. Memang suatu kondisi yang tidak mudah bagi orang tua ketika menghadapi realita bahwa anak kandungnya memiliki kondisi yang berbeda dari anak-anak normal. Seperti terungkap dalam penelitian Belsky, Lang, dan Rovine (1985, dalam Hunt \& Marshall, 2005) bahwa kehadiran anak yang memiliki kebutuhan khusus akan dapat meningkatkan stres dan bahkan keretakan dalam keluarga.

Terkait dengan stres tersebut, penelitian yang dilakukan oleh Blacher (1984, dalam Heward, 2003) menemukan adanya tiga tahap penyesuaian yang pada umumnya ditunjukkan oleh orang tua yang menjadi subjek penelitian, yaitu: 1. tahap dimana orang tua mengalami berbagai krisis emosional seperti shock, ketidakpercayaan, dan pengingkaran terhadap kondisi anaknya; 2. Tahap ketika rasa tidak percaya dan pengingkaran yang terjadi diikuti oleh perasaan-perasaan dan sikap negatif seperti marah, menyesal, menyalahkan diri sendiri, malu, depresi, rendah diri di hadapan orang lain, menolak kehadiran anak, atau menjadi overprotective; 3 . Tahap terakhir pada saat orang tua telah mencapai suatu kesadaran terhadap situasi yang dihadapi, serta bersedia untuk menerima kondisi anak yang berbeda.

Tahap-tahap penyesuaian yang telah dipaparkan di atas, membuka pemahaman bahwa suatu hal yang wajar apabila orang tua membutuhkan waktu yang tidak sedikit untuk dapat berdaptasi dengan hadirnya anak yang memiliki kebutuhan khusus, sebelum pada akhirnya mereka mampu menerima kenyataan tersebut. Namun demikian, hal yang wajar ini akan menjadi permasalahan yang cukup serius apabila orang tua terlalu lama terjebak dalam berbagai perasaan yang negatif seperti kesedihan, kemarahan, kehilangan harapan, pengingkaran, ataupun penolakan atas keadaan yang tidak diinginkannya. Oleh karena itu, sebagai orang tua diharapkan memiliki tingkat kematangan emosi yang baik dalam melakukan pendampingan terhadap anak yang memiliki kebutuhan khusus.

Patty (1982: 117) menyatakan bahwa emosi adalah perasaan terkejut, takut, sedih, marah, gembira yang bersifat bukan saja rohani tetapi juga jasmani. Emosi dapat dirumuskan sebagai suatu keadaan yang merangsang dari organisme, mencakup perubahan-perubahan yang disadari, yang mendalam sifatnya, dan perubahan perilaku (Chaplin, 2002: 163). Adapun Crow \& Crow (dalam Sunarto \& Hartono, 1995:120) menyatakan bahwa emosi adalah: "An emotion, is an affective experience that accompanies generalized inner adjustment and mental and psychological stirredup state in the individual, and that shows it self in this overt behavior" dengan kata lain emosi adalah pengalaman afektif yang disertai penyesuaian dari dalam diri individu tentang keadaan mental, fisik, dan berwujud suatu tingkah laku yang tampak.

Secara umum emosi adalah keadaan perasaan yang timbul secara otomatis pada manusia dalam menghadapi situasi-situasi tertentu, seperti rasa cemas, sayang, sedih, marah, cinta yang dialami individu dalam batinnya, sehingga untuk mengadakan hubungan dengan sekitarnya mungkin terganggu. Kematangan emosi adalah kemampuan seseorang untuk menyesuaikan diri, menempatkan diri, dan menghadapi berbagai kondisi dengan suatu cara tertentu. Tentu saja setiap orang tua tidak akan sama bila ditinjau dari sisi yang satu ini. 
Di antara mereka ada yang telah mencapai kematangan dan mencapai fase kedewasaan secara emosi dan psikologis, namun ada pula yang belum matang (Mutadin, Zainun: 2002).

Hurlock (2000: 213) mengemukakan bahwa petunjuk kematangan emosi pada diri individu adalah kemampuan individu untuk menilai situasi secara kritis terlebih dahulu sebelum bereaksi secara emosional, tidak lagi bereaksi tanpa berpikir sebelumnya seperti anak-anak atau orang yang tidak matang, sehingga akan menimbulkan reaksi emosional yang stabil dan tidak berubah-ubah dari satu emosi atau suasana hati ke emosi atau suasana hati yang lain. Individu dikatakan telah mencapai kematangan emosi apabila mampu mengontrol dan mengendalikan emosinya sesuai dengan taraf perkembangan emosinya.

Dalam berbagai kasus dapat kita amati reaksi emosi orang tua atau keluarga yang merasa bersalah atau merasa berdosa atas kehadiran anaknya yang menyandang kelainan, perlakuan orang tua atau keluarga dalam menebus dosa atau mengurangi perasaan bersalah dilakukan dengan cara mencurahkan kasih sayangnya secara berlebihan kepada anaknya yang memiliki kebutuhan khusus. Bahkan tak jarang perlakuan orang tua terhadap anaknya terkesan sangat melindungi segala kepentingannya. Penyikapan orang tua atau keluarga yang demikian pada gilirannya justru akan membuat anak berkebutuhan khusus semakin tidak berdaya (Efendi, 2010:16).

Kasus lain yang dapat dicontohkan, reaksi emosi orang tua yang merasa kecewa atas kehadiran anaknya yang menyandang kelainan. Perasaan kecewa ini muncul setelah mengetahui bahwa anak yang dilahirkan tidak memenuhi harapanya. Rangkaian selanjutnya akan menimbulkan perasaan putus asa atau frustasi pada orang tua melihat kenyataan yang ada. Tumbuh kembangnya penyikapan orang tua atau keluarga yang merasa kecewa, disebababkan mereka memiliki anggapan bahwa kehadiran anak berkebutuhan khusus dapat menurunkan martabat atau gengsi orang tua. Penolakan ini dapat menimbulkan efek psikologis buat anak yakni timbulnya perasaan tidak aman, rendah diri, serta merasa tak berharga atau tidak berguna (Efendi, 2010:16).

Berdasarkan dua contoh kasus di atas dapat terlihat bahwa setiap orang tua yang memiliki anak berkebutuhan khusus menerapkan solusi yang berbeda-beda dalam melakukan pendampingan terhadap anak yang berkebutuhan khusus. tingkat stres yang dialami orang tua, kematangan emosi yang dimiliki orang tua sangat berpengaruh terhadap cara orang tua melakukan pengasuhan terhadap anak. Orang tua pasti berkeinginan untuk dapat selalu memberikan yang terbaik buat buah hatinya. Dalam hal ini, konsep koping merupakan hal yang penting untuk dibicarakan. Konsep koping menunjuk pada berbagai upaya, baik mental maupun perilaku, untuk menguasai, mentoleransi, mengurangi, atau meminimalisasikan suatu situasi atau kejadian yang penuh tekanan. (Mutadin,Zainun: 2002). Koping merupakan suatu proses di mana individu berusaha untuk menangani dan menguasai situasi yang menekan akibat dari masalah yang sedang dihadapinya.

Dalam mengatasi stres yang dialami, orang tua menggunakan dua jenis koping, yaitu problem focused coping, dan emotion focused coping. (Lazarus \& Folkman (1984)). Beberapa contoh kasus penelitian, orang tua yang menerapkan bentuk koping yang berorientasi pada masalah akan berusaha mencari pengobatan alternatif ke berbagai tempat seperti ke ahli terapi, dan pijat akupuntur. Pengobatan ini dilakukan untuk memperoleh kesembuhan anak. (yunida, Noor: 2010)

Sedangkan orang tua yang menerapkan bentuk koping yang berfokus pada emosi akan mengontrol stres yang muncul dengan bersabar tidak mengeluh kepada Tuhan, menyesuaikan diri dengan keadaan anak dengan cara bersikap santai menghadapi anak dan mengikuti kemauan anak, serta berdoa untuk membuat hati partisipan menjadi tenang. (yunida, Noor: 2010)

Mengetahui kenyataan bahwa buah hati kita menderita gangguan dan tidak dapat berfungsi normal tentu menjadi beban dan sumber stres yang besar dalam hidup. Tidak jarang orang tua mengingkari kenyataan yang ada tersebut. Satu dari sekian banyak orang tua yang memiliki anak berkebutuhan khusus mengatakan "andai saja bisa tawar menawar dengan Allah, saya sudah pasti akan berada di urutan pertama melakukannya. tetapi memiliki anak berkebutuhan khusus bukanlah sesuatu yang bisa ditawar. mau tidak mau, suka tidak suka, harus diterima. penerimaan orangtua ABK inilah yang menjadi sebuah 'pekerjaan' besar. Urusan penerimaan adalah urusan hati“" (Arinaresmi, 2009).

Hal tersebut menunjukkan bahwa tidak mudah menjalani kenyataan akan hadirnya anak berkebutuhan khusus dalam sebuah keluarga, 
karena orang tua manapun ingin anaknya 'baikbaik' saja. Beberapa orang tua bahkan menunda pergi ke dokter atau psikiater karena khawatir akan menerima berita buruk. Hal ini diperkuat dengan penelitian yang dilakukan oleh Hill dkk (1999, dalam santrock 2003) menunjukkan bahwa pengalaman dan perasaan partisipan dalam menghadapi anaknya yang memiliki kebutuhan khusus meliputi: orang tua merasa marah, khawatir dan takut akan masa depan anaknya, takut anak ditolak oleh lingkungan, memiliki rasa bersalah, sedih, tetapi juga ada yang senang dan bangga. Menghadapi kenyataan bahwa anak-anaknya berkebutuhan khusus, partisipan melakukan tindakan (coping strategy) yaitu mencoba berpikiran bijaksana, mencoba mencari dukungan sosial dan emosi, ada juga yang menerima dengan pasrah. Kesimpulan penelitian ini menunjukkan, sukar bagi orang tua untuk bisa menerima keadaan anaknya yang berkebutuhan khusus tanpa bantuan para profesional, orang tua membutuhkan dorongan semangat untuk memberdayakan diri mereka.

Pada penelitian ini, peneliti memakai sampel ibu, karena pada umumnya seorang ibu lebih banyak berperan dalam pengasuhan anak daripada ayah. Anak mendapatkan kasih sayang yang lebih dari seorang ibu. Keterikatan dengan ibu mempunyai konsekuensi jangka panjang. Ia memberi dasar rasa aman emosional untuk anak, dan membentuk dasar bagi pengaruh orang tua selanjutnya pada anak (Mussen, 1989).

berdasarkan uraian diatas dapat disimpulkan bahwa anak berkebutuhan khusus merupakan fenomena nyata dalam kehidupan kita. Tingginya tingkat stres, kurangnya kematangan emosi serta penerapan jenis perilaku koping orang tua dalam hal ini ibu yang tidak sesuai justru akan menghambat perkembangan anak yang memiliki kebutuhan khusus. Oleh sebab itu maka peneliti merasa perlu melakukan penelitian tentang Hubungan Tingkat Stressed, Kematangan Emosi, dengan Jenis Perilaku Koping Stres Pada Orang Tua ABK di Kota Malang.

\section{METODE}

\section{Subjek Penelitian}

Subjek dalam penelitian ini adalah ibu-ibu yang memiliki anak berkebutuhan khusus yang menyekolahkan anaknya di SDLB di kota Malang. SDLB tersebut meliputi SDLB Bakti Luhur, jalan Raya Dieng 40 Kec Sukun; SDLB Negeri Kedung Kandang, jalan H. Ali Nasrudin No 2 Kec. Kedung
Kandang; SDLB YPAC, jalan R. Tumenggung Suryo 39 Kec. Blimbing; SDLB-B YPTB, jalan B S Riadi 126 Kec. Klojen; SDLB Putra Jaya, jalan Nusa Indah No.11A Kec. Lowokwaru. Adapun ciri-ciri spesifik subyek penelitian, sebagai berikut:

1. Ibu yang tinggal dan menetap di kota Malang, serta memiliki satu anak berkebutuhan khusus.

2. Berada dalam keluarga yang utuh (Suami dan Istri tinggal dalam satu rumah)

3. Usia ibu antara $18-35$ tahun

\section{Instrumen Penelitian}

1. Skala Tingkat Stres

Skala tingkat stress dalam penelitian ini adalah instrumen skala yang dikembangkan menggunakan teori Selye (dalam Hardjana, 2000). Yang menyebutkan bahwa terdapat empat indikator untuk mengukur tingkat stres seseorang yaitu: fisikal, intelektual, emosional, dan interpersonal. Skala Stres ini merupakan instrumen pengukur untuk menentukan tinggi rendahnya stres yang dialami subyek. Stres ini diukur berdasarkan jumlah skor yang didapat dari subyek atas jawaban dari pernyataanpernyataan sikap. Semakin rendah nilai yang didapat maka semakin rendah pula stres yang dimiliki orang tua yang memiliki anak berkebutuhan khusus.

2. Skala Kematangan Emosi

Skala kematangan emosi dalam penelitian ini adalah instrumen skala yang dikembangkan menggunakan teori hurlock (1999) yang menyatakan bahwa terdapat tiga indikator dalam mendefinisikan kematangan emosi, yaitu:

a. emosi tidak berlebihan dihadapan orang lain melainkan menunggu saat yang lebih tepat untuk mengungkapkan emosinya dengan cara yang dapat diterima.

b. menilai situsi secara kritis terlebih dahulu sebelum bereaksi secara emosional.

c. memiliki reaksi emosi yang stabil.

Kematangan emosi ini diukur berdasarkan jumlah skor yang didapat dari subyek atas jawaban dari pernyataan-pernyataan sikap. Semakin rendah nilai yang didapat maka semakin rendah pula tingkat kematangan emosi yang dimiliki orang tua yang memiliki anak berkebutuhan khusus.

3. Skala Jenis Perilaku Koping Berfokus pada Masalah dan Berfokus pada Emosi 
Skala perilaku koping dalam penelitian ini adalah instrumen skala yang dikembangkan menggunakan teori Folkman \& Lazarus, (1988) yang menyatakan bahwa terdapat dua jenis perilaku koping yaitu:

a. koping terarah pada masalah dengan beberapa indikator yaitu active coping (Melakukan koping aktif), Planning (Perencanaan), Suppression of Competing Activities (menekan aktivitas lain), Restraint coping (menahan diri), Seeking Support for Instrumental Reason (mencari dukungan sosial).

b. Koping yang Terarah pada Emosi dengan beberapa indikator yaitu Seeking Support for Instrumental Reason (mencari dukungan sosial), Positive Reinterpretasi and Growth (menafsirkan secara positif), Acceptance (penerimaan), Turning to Religion (berpegang pada agama), Denial (penolakan).

Perilaku koping ini diukur berdasarkan jumlah skor yang didapat dari subyek atas jawaban dari pernyataan-pernyataan sikap. Semakin rendah nilai yang didapat maka semakin nampak bahwa subjek dalam hal ini orang tua yang memiliki anak berkebutuhan khusus menerapkan jenis koping yang terarah pada emosi, sedangkan semakin tinggi nilai yang didapat maka subjek dalam hal ini orang tua yang memiliki anak berkebutuhan khusus menerapkan jenis koping yang terarah pada masalah dalam menghadapi stres yang dialaminya

\section{HASIL DAN PEMBAHASAN \\ Hasil Analisis Deskriptif. \\ Deskripsi Data Stres}

Data stres diperoleh melalui Skala Stres terdiri dari indikator-indikator yang dikemukakan oleh Selye (dalam Hardjana, 2002) yang mengacu pada indikator-indikator antara lain: fisikal, intelektual, emosional, dan interpersonal. Hasil penelitian terhadap 60 subyek menunjukkan bahwa data stres yang diperoleh adalah skor terendah 46, skor tertinggi 110 , mean 73,77 dan standar deviasi 17 , 25 .

hasil penelitian terhadap 60 orang tua yang memiliki anak berkebutuhan khusus di Malang terdapat 6 orang tua $(10 \%)$ yang memiliki stres sangat tinggi, 24 orang tua $(40 \%)$ yang memiliki stres tinggi, 27 orang tua (45\%) yang memiliki stres rendah, dan 3 orang tua $(5 \%)$ yang memiliki stres rendah sekali. Hal ini berarti bahwa tingkat stres yang dialami orang tua yang memiliki anak berkebutuhan khusus di kota Malang tergolong sangat bervariatif

\section{Deskripsi Data Kematangan Emosi}

Data kematangan emosi diperoleh melalui Skala Kematangan Emosi terdiri dari indikatorindikator yang dikemukakan oleh Hurlock (1999) yang mengacu pada indikator-indikator antara lain: ekpresi emosi, penilaian situasi, reaksi emosi. Hasil penelitian terhadap 60 subyek menunjukkan bahwa data kematangan emosi yang diperoleh adalah skor terendah 68 , skor tertinggi 112 , mean 90,27 dan standar deviasi 13,67.

Hasil penelitian terhadap 60 orang tua yang memiliki anak berkebutuhan khusus di Malang terdapat 6 orang tua $(10 \%)$ yang memiliki tingkat kematangan emosi "sangat matang", 21 orang tua (35\%) yang memiliki tingkat kematangan yang "matang", 32 orang tua $(53,33 \%)$ yang memiliki tingkat kematangan emosi "cukup matang", dan 1 orang tua $(1,67 \%)$ yang memiliki tingkat kematangan emosi "kurang matang". Hal ini berarti bahwa tingkat kematangan emosi yang dimiliki orang tua yang memiliki anak berkebutuhan khusus di kota Malang tergolong cukup matang karena sebagian besar responden memiliki tingkat kematangan emosi yang matang dan cukup matang.

\section{Deskripsi Data Jenis Perilaku Koping}

Data Jenis Perilaku Koping diperoleh melalui Skala Jenis Perilaku Koping yang terdiri dari dua jenis perilaku koping yang dikemukakan oleh Folkman dan Lazzarus (1988) yaitu koping yang berfokus pada masalah, dan koping yang berfokus pada emosi. Data Perilaku koping dideskripsikan berdasarkan jenisnya, yaitu perilaku koping yang berfokus pada masalah dan yang berfokus pada emosi. Hasil penelitian terhadap 60 subyek menunjukkan bahwa data jenis perilaku koping berfokus pada masalah yang diperoleh adalah skor terendah 27 , skor tertinggi 52, mean 42,40 dan standar deviasi 6,23

hasil penelitian terhadap 60 orang tua yang memiliki anak berkebutuhan khusus di Malang terdapat 3 orang tua $(5 \%)$ yang memiliki jenis perilaku koping yang berfokus pada masalah dengan tingkat sangat tinggi, 33 orang tua (55\%) yang memiliki jenis perilaku koping yang berfokus pada masalah dengan tingkatan tinggi, 19 orang tua $(31,67 \%)$ yang memiliki jenis perilaku koping yang berfokus pada masalah dengan tingkat rendah, dan 
5 orang tua $(8,33 \%)$ yang memiliki jenis perilaku koping yang berfokus pada masalah dengan tingkatan sangat rendah.

Sedangkan Hasil penelitian terhadap jenis perilaku koping yang berfokus pada emosi pada 60 subyek menunjukkan bahwa data jenis perilaku koping yang diperoleh adalah skor terendah 24, skor tertinggi 42, mean 35,20 dan standar deviasi 4,57

hasil penelitian terhadap 60 orang tua yang memiliki anak berkebutuhan khusus di Malang terdapat 2 orang tua $(3,33 \%)$ yang memiliki jenis perilaku koping yang berfokus pada emosi dengan klasifikasi sangat tinggi, 35 orang tua $(58,33 \%)$ yang memiliki jenis perilaku koping yang berfokus pada emosi dengan klasifikasi tinggi, 19 orang tua $(31,67 \%)$ yang memiliki jenis perilaku koping yang berfokus pada emosi dengan klasifikasi rendah, dan 4 orang tua $(6,67 \%)$ yang memiliki jenis perilaku koping yang berfokus pada emosi dengan klasifikasi sangat rendah.

\section{Hasil uji Hipotesis}

Hubungan Antara Tingkat Stres dengan Jenis Perilaku Koping Orang Tua ABK di kota Malang

Hasil penghitungan korelasi point biserial diperoleh nilai rpbis $=0,453$ dengan signifikasi sebasar 0,000. Oleh karena nilai signifikasi < 0,05 maka dapat disimpulkan bahwa terdapat hubungan antara variabel tingkat stress dengan jenis perilaku koping orang tua ABK di kota Malang

Dilihat dari tanda koefisien korelasi rpbis $=0,453$ bertanda positif maka dapat disimpulkan bahwa kenaikan nilai variabel tingkat stress sebesar 0,453 akan berdampak kepada kenaikan nilai jenis perilaku koping sebesar 0,453

\section{Hubungan Antara Kematangan Emosi dengan Jenis Perilaku Koping Orang Tua ABK di kota Malang}

Hasil penghitungan korelasi point biserial diperoleh nilai rpbis $=-0,252$ dengan signifikasi sebasar 0,04. Oleh karena nilai signifikasi < 0,05 maka dapat disimpulkan bahwa terdapat hubungan antara variabel kematangan emosi dengan jenis perilaku koping orang tua $\mathrm{ABK}$ di kota Malang Dilihat dari tanda koefisien korelasi rpbis $=-0,252$ bertanda negatif maka dapat disimpulkan bahwa kenaikan nilai variabel kematangan emosi sebesar 0,252 akan berdampak kepada penurunan nilai jenis perilaku koping sebesar 0,252
Hubungan Antara Tingkat Stres dan Kematangan Emosi dengan Jenis Perilaku Koping Orang Tua ABK di kota Malang

Hasil penghitungan analisis regresi linier ganda antara variabel tingkat stress, kematangan emosi, dengan jenis perilaku koping berfokus pada masalah diperoleh nilai $F_{\text {hitung }}$ sebesar 20,283 dengan signifikansi sebesar 0,000. Oleh karena $F_{\text {hitung }}$ memiliki signifikansi sebesar 0,000 (sig < 0,05) maka dapat disimpulkan bahwa terdapat hubungan antara variabel tingkat stres dan kematangan emosi dengan jenis perilaku koping yang berfokus pada masalah

Sedangkan hasil penghitungan analisis regresi linier ganda antara variabel tingkat stress, kematangan emosi, dengan jenis perilaku koping berfokus pada emosi diperoleh nilai $\mathrm{F}_{\text {hitung }}$ sebesar 17,338 dengan signifikansi sebesar 0,002. Oleh karena $F_{\text {hitung }}$ memiliki signifikansi sebesar 0,002 (sig < 0,05) maka dapat disimpulkan bahwa terdapat hubungan antara, variabel tingkat stres dan kematangan emosi dengan jenis perilaku koping yang berfokus pada emosi

\section{PENUTUP}

Kesimpulan

1. Tingkat stressed orang tua yang memiliki anak berkebutuhan khusus di kota Malang tergolong sangat bervariatif. Dari 60 subjek penelitian diketahui bahwa $10 \%$ ibu memiliki tingkat stressed sangat tinggi, $40 \%$ ibu memiliki tingkat stressed tinggi, $45 \%$ ibu memiliki tingkat stressed rendah, 5\% ibu memiliki tingkat stressed rendah sekali

2. Kematangan emosi orang tua yang memiliki anak berkebutuhan khusus di kota Malang sangat variatif. Dari 60 subjek penelitian diketahui bahwa $10 \%$ ibu memiliki kematangan emosi yang sangat matang, 35\% ibu memiliki kematangan emosi yang matang, $53,33 \%$ ibu memiliki kematangan emosi yang cukup matang, dan $1,67 \%$ ibu memiliki kematangan emosi kurang matang

3. Jenis Perilaku koping orang tua $\mathrm{ABK}$ di kota Malang sangat bervariatif, Dari 60 subjek penelitian diketahui bahwa $46,67 \%$ ibu memiliki jenis koping berfokus pada masalah tinggi dan koping berfokus pada emosi tinggi, $13,33 \%$ ibu memiliki jenis koping berfokus pada masalah tinggi dan koping berfokus pada emosi rendah, $15 \%$ ibu memiliki jenis koping berfokus pada masalah rendah dan koping 
berfokus pada emosi tinggi, $25 \%$ ibu memiliki jenis koping berfokus pada masalah rendah dan koping berfokus pada emosi rendah

4. Terdapat hubungan antara tingkat stressed, kematangan emosi dengan jenis perilaku koping yang berpusat pada masalah $(\mathrm{F}=20,283$, sig $=0,00<0,05)$ dan juga terdapat hubungan yang simultan antara tingkat stressed, kematangan emosi dengan jenis perilaku koping yang terpusat pada emosi $\mathrm{F}=17,338$ sig $=0,002<0,05)$

5. Terdapat hubungan positif yang signifikan antara tingkat stress dengan jenis perilaku koping dengan rpbis $=0,453$, sig. $0,000<0,05$ artinya semakin tinggi tingkat stressed maka ibu memiliki kecenderungan memiliki skor tinggi pula skor jenis perilaku koping orang tua ABK di kota Malang. Hal ini berarti ibu memiliki kecenderungan untuk menerapkan jenis perilaku koping yang berfokus pada emosi

Terdapat hubungan negatif yang signifikan antara kematangan emosi dengan jenis perilaku koping dengan rpbis $=-0,252$, sig. $0,04<0,05$ artinya semakin tinggi skor kematangan emosi maka ibu memiliki kecenderungan memiliki skor rendah pada jenis perilaku koping orang tua ABK di kota Malang. Hal ini berarti ibu memiliki kecenderungan untuk menerapkan jenis perilaku koping yang berfokus pada masalah

\section{Saran}

\section{Bagi Ibu}

Ibu diharapkan lebih mampu untuk bersikap terbuka kepada guru, maupun konselor terkait dengan kondisi perkembangan anak, sehingga akan mampu menciptakan kondisi belajar yang mendorong anak lebih proaktif dalam mengatasi masalah, meningkatkan ketrampilan dan dukungan dalam belajar, emosi, dan sosial. Selain itu diharapkan Ibu lebih proaktif untuk mencari informasi berkaitan dengan cara-cara pendampingan terhadap anak sehingga Ibu akan mendapatkan pemaknaan yang proposional, dengan demikian, orang tua akan lebih mudah menerima kondisi dan realitas dirinya tanpa ada perasaan mencela atau menyalahkan diri sendiri yang tidak rasional.

2. Bagi Suami dan Anggota Keluarga Lain

Bagi suami dan keluarga diharapkan mampu memberikan perasaan aman dan keterbukaan dalam hubungan sosialnya, sehingga orang tua yang memiliki anak berkebutuhan khusus tidak merasa terkucilkan dan mampu berbagi untuk membicarakan masalah pribadinya. Hal ini akan membantu orang tua untuk mampu menerapkan perilaku koping yang tepat dalam berdaptasi dan meredakan ketegangan pada konflik terhadap stressor yang dialami.

3. Bagi Tenaga Ahli Profesi (Guru dan konselor).

Bagi guru dan konselor, diharapkan mampu memberikan serta mengkomunikasikan informasiinformasi berkaitan dengan cara pendampingan yang efektif, sehingga akan membatu orang tua untuk lebih mampu menciptakan suasana pendidikan yang tepat, berkesinambungan antara pendidikan yang diterapkan di sekolah dengan pendidikan yang diterapkan di rumah. Selain itu guru dan konselor diharapkan lebih mampu untuk menciptakan strategi-strategi yang membantu orang tua dalam memahami dan menguasai emosi nya. Misalnya dengan membentuk forum diskusi dan sharing bersama antara orang tua, guru dan konselor.

4. Bagi Peneliti Selanjutnya.

Penelitian ini masih memiliki kekurangan dan keterbatasan. Pihak peneliti menyadari keterbatasan dalam penelitian ini baik menyangkut instrumen penelitian, jumlah subyek penelitian maupun pengambilan data di lapangan. Kesimpulan dan saran yang penulis kemukakan hendaknya dapat dijadikan bahan pemikiran dan pertimbangan bagi peneliti selanjutnya, sehingga hasil-hasil penelitian berikutnya diharapkan dapat memberikan sumbangan dalam bidang keilmuan psikologi yang berkaitan dengan pendampingan orang tua terhadap anak berkebutuhan khusus

\section{DAFTAR PUSTAKA}

Albin. 1991. Emosi Bagaimana Mengenal dan Menerima dan Mengarahkannya. Yogyakarta: Kanisius

Arinaresmi, P. 2009. menata-hati. (Online) (http://allaboutbalqiz.blogspot.com/2009/0 8/ menata-hati.html, diakses tanggal 29 Pebruari 2011)

Atkinson, smith. Dkk (2000). Introduction to psychology (13th edition) Harcourt College publisher

Adzikriyah, Evi Afifah. 2000. Hubungan antara kematangan emosi dengan kompetensi social remaja. Jurnal Psikodinamik, The Indonesian Journal of Psychology Vol.2 
No.1. Malang: Fakultas Psikologi

Universitas Muhamadiyah Malang.

Arikunto, Suharsimi. 2002. Prosedur Penelitian Suatu Pendekatan Praktek. Rineka Cipta: Jakarta.

Azwar, S. 2003. Penyususnan Skala Psikologi. Cetakan ke 4. Yogyakarta: Pustaka Pelajar

Azwar, S. 2003. Reliabilitas dan Validitas.

Yogyakarta: Pustaka Pelajar Ofset.

Cooper, L. and Payne. 1991. Personality \& Stres; individual difference in the stress procces. New York: John Wiley \& Sons

Chaplin, J.P (1997). Kamus Lengkap Psikologi (terjemahan dari kartini kartono). Jakarta. Raya grafindo persada

Crow \& Crow. 1963. An Outline of General Psychology. Paterson, New Jersey: Littlefield, Adams \& CO.

Efendi, Mohammad. 2010. Sistem Penilaian Khusus Untuk PLB. Malang: PSG 15 Universitas Negeri Malang.

Goleman, Daniel. 1999. Emotional Intelligence: Kecerdasan Emosional. Jakarta: PT. Gramedia Pustaka Utama

Greenglass, E, dkk. 1999. The Proactive Coping Inventory $(P C I)$ : $\quad A$ Multidimensional Research Instrument. Paper presented at the 20th International Conference of the Stress and Anxiety Research Society (STAR).Cracow, Poland, July 12-14, 1999a.

Hadi, S. 2001. Metodologi Research Jilid 1. Yogyakarta: Andi Offset

Hardjana, Agus M. 2000. Stress tanpa Distress: Seni Mengolah Stress. Yogyakarta: Kanisius

Harian Joglo Semar. (2010, 3 Maret). Pendidikan Anak Berkebutuhan Khusus 249.000 Orang Belum Tersentuh. (online) http://harianjoglosemar.com/berita/pendidi kan-anak-berkebutuhan-khusus-249000orang-belum-tersentuh-10611.html, diakses 19 Oktober 2011

Hasan, Haekal Ghazy. 2002. Pengaruh Kematangan Emosional Terhadap
Pemilihan Strategi Coping Pada Remaja. skripsi (tidak diterbitkan). Malang: Fakultas Psikologi Universitas Muhamadiyah Malang

Heward W.L. 2003. Exceptional Children, an Introduction to special education. New Jersey: Merril Practice Hall

Hunt \& Marshal. 2005. Exceptional Children \& Youth. Boston: Houghton Mifflin Company

Hurlock, E. B. 1999. Psikologi Perkembangan : Suatu Pendekatan Sepanjang Rentang Kehidupan Edisi kelima.. Jakarta : Erlangga.

Hurlock, EB. 2000. Development Psychology: A Live Span Approach. $5^{\text {th }}$ edition. New York: Mc Graw - Hill Kogusukha Ltd.

Johnston, C., \& dkk. 2003. Factors Associated with Parenting Stress in Mothers

of Children with Fragile $X$ Syndrome. Developmental and Behavioral Pediatric, August, Vol 24, No. 4, 267-275

Kazdin, A.E. \& Whitley, M.K. 2003. Treatment of Parental Stress to Enchance Therapeutic Change Among Children Reffered for Aggressive and Antisocial Behaviour. Journal of Consulting and Clinical Psychology. 71, $504-51$

Lazarus, R.S. 1991. Emotion And Adaption. New York: Oxford University Pres

Lazarus, R \& Folkman S. 1984. Stress, Apprasial, and Coping. New York: Springer

Lazarus, R.S. 1969. Pattern Adjusment. Tokyo: Mc.Graw Hill

Maramis, W.F. 1994. Ilmu Kedokteran Jiwa. Surabaya: Airlangga University Press

Mappiare, Andi. 1988. Psikologi Orang Dewasa. Surabaya: Usaha Nasional.

Mercer, CD.1983. Students With Learning Disabilities (2 nd ed). Ohio: A.Bell \& Howell CO.

Moerdiani, A.S. 1987. Psikologi Anak Luar Biasa. Bandung: Universitas Islam Nusantara

Musfiroh, Silvina. 2010. Koping Stres pada Difabel Korban Gempa Bumi. Tesis Tidak 
Aryudho Widyatno, Adi Atmoko, \& Diantini Ida Viatrie, Hubungan Tingkat Stres, Kematangan Emosi... | 118

Diterbitkan. Surakarta: Universitas Muhammadiyah Surakarta.

Mussen D.H, dkk. 1989. Perkembangan dan Kepribadian Anak. Jakarta: Arcan

Mu'tadin, Z. (2002) kemandirian sebagai kebutuhan psikologis pada remaja. http://www.epsikologi.com/remaja.050602.htm [online]

Patty F. 1982. Pengantar Psikologi Umum. Surabaya: Usaha Nasional

Pervin, L.A. 1996. The Science of Personality. New York: John Wiley and Sons, IAC

Poerwandari K. 2006. Stres, Trauma, dan Stres Pasca Trauma (online diakses tanggal 9 oktober 2009)

Rice, Philip L. 1992. Stress and health $\left(2^{\text {nd }} e d\right)$. California: Brooks/Cole Publishing Company.

Singgih, Santoso. 2000. SPSS Statistik Parametrik edisi Kelima. Jakarta: PT Slerk Gramdi

Santrock, J.W. 2003. Adolescence : Perkembangan Remaja. Jakarta: Erlangga

Sarafino, E.P (1994). Health psychology (2nd ed). New York: john wiley and sons

Sarwono, W.S., 2005, Psikologi Remaja, Jakarta, Rajawali Press

Schulltz, Duane. 1991. Psikologi Pertumbuhan. Yogyakarta: Kanisius

Selye, Hans. 1976. The stress of life. New York: Mc Graw Hill

Sukardi, Anggraini. 1999. Hubungan Antara Kematangan Emosi dan Kepuasan dalam Hubungan Pacaran Pada Mahasiswa UI. Skripsi Tidak Diterbitkan. Jakarta: Fakultas Psikologi UI

Sukmadinata, Nona Syaodih. 2008. Memahami Emosi Individu (online). (http// epsikologi.com. diakses 9 Oktober 2009)

Sunarto \& Hartono, B. Agung. 1995.

Perkembangan Peserta Didik. Jakarta: Rineka Cipta Wahjosumidjo

Suyanto, S. 2005. Konsep Dasar Pendidikan Anak Usia Dini. Jakarta: Departemen Pendidikan Nasional.
Taylor, S.E. 1999. Health Psychology $\left(4^{\text {th }} e d\right)$. Singapore: Mc.Graw - Hill Book CO.

Walgito, Bimo. 2003. Pengantar Psikologi Umum. Yogyakarta: Andi Offset

YCHI Center. 3 April 2011. Dukungan Program Autism Care Indonesia. www.ychicenter.org/ index.php?option.com_content \& view, (online) diakses 19 Oktober 2011

Yudiarso, Ananta, dkk. 2004. Stres dan perilaku koping pada remaja penyandang diabetes mellitus tipe 1, Anima Indonesian Psychological Journal Vol 19 No 4. Surabaya: Fakultas Psikologi Universitas Surabaya.

Yusuf, S. 2005. Psikologi Perkembangan Anak dan Remaja. Bandung: PT. Remaja Resdakarya.

Yunida, Noor \& Andriany, Megah. 2010. Stres dan Koping Keluarga Dengan Anak Tunagrahita di SDLB C dan SDLB C1 Widya Bakti Semarang. Semarang 